purely geometrical work that precedes. Here again a treatment of deformable bodies and of elasticity is added to the more usual treatment of the mechanics of rigid bodies.

As a whole the work seems a most satisfactory compilation, to which the author has added materially by careful readjusting and supplementing existing work. The bibliography and references are good.

In being late, the present review has the advantage of referring the readers to a number of admirable reviews already in print; among those most readily accessible are: $R$. S. Ball, Nature, LXXXI., July, 1909, p. 34; Longley, Bull. Amer. Math. Soc., XVI., 1910, p. 493; Revue Generale des Sciences, 21, 1910 , p. 75. Of these, that by Ball in $\mathrm{Na}$ ture is of course the most interesting on account of the close relation he holds to this theory.

Göttingen, Germany,

E. R. HEDRICK August, 1911

Material for Permanent Painting. A Manual for Manufacturers, Art Dealers, Artists and Collectors. By Maximilian Toch. New York, D. Van Nostrand Co. Pp. 208. Price, $\$ 2.00$.

It would seem that Mr. Toch had gotten into this small compass practically all that an artist need know about his materials from the standpoint of permanency. Judging from the author's name, one would expect a work dealing solely with pigments: only about half of the book is so employed, the remainder consisting of interesting chapters on the history of painting, preparation of canvasses and other foundations, the causes and remedies for cracking of paintings, their renovation, and the oils and other media used in their production. The articles on the photochemical effects of light and the proper use of madder are especially noteworthy and merit careful study.

Some slight slips in proof reading or unusual spellings are in evidence as, quick silver (two words), cinibar, sulphureted, tuscan, Vanquelin and Guinet; but these will doubt- less disappear in the next edition. Indian yellow is stated to be made from camel dung, whereas the commonly accepted source is cow urine.

The work admirably fills a long-felt want and a good knowledge of its contents should be part of the equipment of every painter.

A. H. GILL

\section{NOTES ON METEOROLOGY AND CLIMATOLOGY}

THe Savannah-Charleston hurricane of August 27-28, 1911, has been made the subject of a special report by the United States Weather Bureau. This storm resulted in the loss of 17 lives, while the damage to property was estimated at $\$ 1,000,000$. The synoptic weather charts which form a part of the bulletin show that the storm lingered off the coast for four days before its approach was detected on shore. Though no wireless reports concerning the hurricane had been received, the weather officials in the two cities mentioned observed the characteristics which usually precede such a storm on the morning of August 27. Acting upon orders from the Washington office, they immediately sent out cautionary warnings. The wind continued to increase, and twelve hours later reached a velocity of 106 miles per hour in Charleston. The center of the hurricane reached the coast near Savannah at 8 A.M. of the 28th, the barometer at that station reading 29.02 inches. Moving thence inland, it passed through eastern Georgia with diminishing intensity, recurved over North Carolina, on a course east-northeastward, and passed to sea off the New Jersey coast. It is a noteworthy fact that no storm of tropical or semi-tropical origin has reached the southern or eastern coasts of the United States without warning since September, 1893, when a disturbance of marked intensity devastated the Louisiana coast. At the present time the Weather Bureau is looking forward to the establishment of a service whereby observers regularly employed aboard coast-wise vessels would report weather conditions twice daily to the central office, and thus to provide early infor- 
mation concerning the approach of these destructive storms.

Throughout the greater part of the United States and Europe the excessive heat of the past summer will be long remembered, new maximum temperatures having been observed in many widely separated places. Unprecedented temperatures of $98^{\circ}$ and $99^{\circ} \mathrm{F}$. were observed at Blue Hill Observatory (635 feet above sea-level) on six days during the early part of July, while the mean temperature for the month, $74.5^{\circ} \mathrm{F}$., was the highest experienced in the vicinity in 63 years, which is the length of the record. At the Royal Observatory, Greenwich, new records have also been established. There the mean temperature for the six months, April to September, inclusive, was $60.7^{\circ} \mathrm{F}$., the highest since 1841 . The mean for the three months June, July and August was $66.1^{\circ} \mathrm{F}$., which is $4.9^{\circ}$ in excess of the average for the past 70 years, and $1.0^{\circ}$ higher than any previous summer on record. On August 9 a temperature of $100^{\circ}$ F. was observed at Greenwich, this being $3.0^{\circ}$ higher than any previous record at the Royal Observatory since 1841 . The mean maximum temperature for August was $81.1^{\circ} \mathrm{F}$., another new record. On July 22, August 4 and 9, a black-bulb thermometer exposed to the sun's rays showed a temperature exceeding $160^{\circ} \mathrm{F}$.

UNDER the supervision of its director, Professor R. F. Stupart, the Canadian weather service has recently been carrying on experiments with registering balloons. These ascensions, the first of the kind in Canada, were made from Toronto and Woodstock. Of the balloons sent up enough were recovered to make the experiments successful. Several of the balloons' entered the region of the upper temperature-inversion, and uniformly good heights were attained, the balloon sent up September 9 reaching a height of more than 14 miles. On July 5, the day on which new maximum temperature records were established in many places, the meteorograph on leaving the ground at Woodstock recorded a temperature of $81^{\circ} \mathrm{F}$., while at a height of 9.4 miles it was $-93^{\circ} \mathrm{F}$. Above the latter level the temperature increased slowly with height.

"Die Winde in Deutschland," by Dr. Richard Assmann, director of the Lindenberg Aeronautical Observatory, is a volume prepared at the request of a German aeronautical society. Based upon more than a million ground and free-air observations of wind velocity and direction, it was designed to serve as a meteorological guide book for dirigible balloon transportation in that country. Tables and diagrams set forth in great detail the varied wind data of which an aeronaut must have a knowledge. For Lindenberg, where a kite flight or a balloon ascension has been made every day without a single exception since 1905, the velocities and the frequencies of winds for each of the various directions at every 500-meter level up to 4,000 meters are shown by means of wind-roses. From a meteorological as well as from an aeronautical point of view the volume is a valuable book of reference.

"Weather Science," an "elementary introduction to meteorology," by Mr. F. W. Henkel, has recently appeared. This volume, consisting of 336 pages, is not designed as a textbook, but as a popular work it is very readable indeed. The few slight inaccuracies which occur will doubtless be overlooked by the average reader. This is the first contribution to meteorology made by the author, who is an English astronomer. Dr. Shaw, the head of the English weather service, has also completed a book, now in the hands of a publisher, called "Forecasting Weather." This volume, written primarily for aeronauts, is based upon the results in dynamic meteorology obtained by the Meteorological Office during the last ten years. A second edition of Mr. H. G. Busk's "What will the Weather be?" has also made its appearance.

Forest Service Bulletin No. 86 contains a paper, "Windbreaks: their Influence and Value," by Mr. Carlos G. Bates, which deals with a problem that is of interest from the point of view of meteorology, as well as of forestry and agriculture. Windbreaks, he 
says, may be profitably employed in much of the agricultural portion of the United States. The distance at which the effect of the trees may be felt averages twenty times their height, although absolute protection of a crop such as corn, in a wind with a velocity of 50 miles per hour, can not be expected beyond a distance of from six to eight times the height of the windbreak. Partial protection is given over a distance of from twelve to fourteen times the height. In extreme cases the efficiency of a windbreak in checking evaporation from the soil may amount to 70 per cent. of the moisture ordinarily lost. Protection in this respect is appreciable for a distance equal to five times the height of the trees in the windward direction, and fifteen or twenty times the height leeward. The absorption of soil moisture by the roots of the trees may in the case of an orchard be appreciable, but need not result in real damage. There is little basis for the belief that windbreaks sap the fertility of the soil. The trees' absorption of soil moisture may, however, reduce the activity of the nitrifying bacteria and cause temporary sterility in the zone of root influence. The effect of a windbreak upon temperature in the region of its influence is much greater than is commonly supposed. The diurnal range in temperature in an area protected by a windbreak is nearly $9^{\circ} \mathrm{F}$. greater than where the air circulates freely. The effect of the superheating of both air and soil in a protected zone is favorable to crops which must begin growth at a time when the heat is barely sufficient for generation. An abstract of the book prepared by Mr. Findley Burns appears in the Journal of the Washington Academy of Science, Vol. I., No. 3.

Two recent studies of the rainfall in special regions are noteworthy. With characteristic German thoroughness, Dr. Hellmann and G. v. Elsner have completed an investigation of certain heavy rains in the valley of the Oder during the years 1888-1903, inclusive, and their relation to the summer high water of that river. The research is published in two volumes, a descriptive text and an atlas, the latter consisting of 55 large colored plates show- ing in detail the distribution of these rains in northern Germany and the meteorological conditions which accompanied them. "The Rains of the Nile Basin" is a report by J. I. Craig, of the Survey Department, Egypt, based upon eleven years' observations. The Nile flood has been of great moment to the residents of that valley from remote antiquity. The author now says "there are hopes that within a few years the prediction of the main features of the flood may be embodied in an algebraic formula such as has already been obtained for the Indian monsoon by Mr. G. T. Walker." It is now well established that "the rainfall in Abyssinia during the flood months is due almost entirely to the precipitation caused by diurnal ascensional movements acting on the southwesterly current which again is kept at the point of saturation by its ascent on to the Abyssinian tableland." The latter current has been traced backward across the Sudan plains, and the watershed between the basins of the Nile and Congo, and thence down the basin of the latter to the South Atlantic.

A COMPLETE summary of the free air data obtained at Mount Weather for the three years ending June 30, 1910, appears in Vol. IV., Part 2, of the Bulletin of the Mount Weather Observatory. The aeorological work is in charge of Dr. William R. Blair, who prepared the summary. On 980 of the 1,096 days of the period, 1,013 ascensions were made-896 by means of kites and 117 by means of captive balloons. Air temperature, air pressure and wind direction aloft were observed, in addition to noting weather conditions and keeping the usual continuous meteorological records at the earth's surface. The temperatures have been grouped by months and by seasons, and the means have been computed for levels 250 meters apart up to 7,250 meters above sea level. Several other valuable tables summarizing the data obtained for the various other elements are included, and their relation with reference to the centers of cyclones and anticyclones are also shown. Previously derived conclusions are verified by means of the new data. Since the beginning of this period the 
aerological work has been extended so that it is now carried on daily, including Sundays. Another innovation at Mount Weather is that of obtaining wind velocity aloft. The series of nine soundings of the free air made in two days is probably unprecedented in the annals of meteorology. This occurred on September 12 and 13 last, when from $6: 37$ in the morning of the first day to 1:06 in the afternoon of the next day the nine kite flights were made one after another, without a pause between them. During the last of these flights a west-northwest wind with a velocity of 69 miles per hour was successfully navigated by a kite at a height of 10,177 feet above sea level.

THE "spectre of the Brocken" is a phenomenon usually observed only from mountain summits. But for two hours on the night of August 6 it was observed by the writer from the top of the Blue Hill Observatory tower, the height being about 700 feet above sea level. Fog, which had been brought in from Boston Harbor by a light easterly wind, arrived at Blue Hill shortly before eight o'clock. Its upper surface, which was very distinct, was about at the level of the upper windows of the tower. The moon, about three-quarters full, was well above the horizon, and a few scattered cirrus streamers were the only high clouds visible. From the top of the ladder on the anemometer poles the surface of the fog stratum had the appearance of a wavy sheet of water. Directly opposite to the moon the observer could see, at an estimated distance of 75 feet, a dark image of himself enlarged about three times his natural size. The image was surrounded by a white light which faded away at its edges, leaving a dark space between it and a broad colorless circle, sometimes called "Ulloa circle" or "white rainbow." The circle was complete and appeared to have a radius of about $22^{\circ}$. When the observer moved the whole apparition moved likewise, proving it to be an entirely subjective phenomenon. It disappeared later when the fog deepened, rendering the moon invisible.

\section{Blue Hill Observatory,}

Andrew H. Palmer

November 1, 1911

\section{SPECIAL ARTICLES}

THE LIFE HISTORY OF A PARASITIC NEMATOdEHABRONEMA MUSCE

Fifty years ago, from Bombay, India, the late H. J. Carter ${ }^{1}$ reported the discovery of nematodes parasitic in the house fly, giving them the name of Filaria muscoe, and suggesting that their investigation might throw light on the life history of the guinea-worm. In the same year Diesing ${ }^{2}$ transferred Carter's species to the genus Habronema, making it the type. Carter's description and figures, though not accurate in all respects, particularly in the interpretation placed on certain details of structure, are sufficient for the recognition of the species. Subsequently to Carter, several writers have mentioned the presence of nematodes in the house fly, in some cases identifying them with Carter's species, in other cases being apparently unaware that the species had ever been described or named. Leidy ${ }^{3}$ noted the occurrence of Habronema musca in about 20 per cent. of flies examined at Philadelphia. Further than occasional records of the occurrence of Habronema muscee in flies, practically nothing up to the present time has been added to Carter's account of the worm, though it has long since become known that this parasite has nothing to do with the guinea-worm.

In the summer of 1910 , the present writer found Habronema musca fairly common in house flies caught at Washington, D. C. The fact that this nematode occurred in the larval stage in flies suggested two alternative hypotheses, first, that the adult was a free living form, second, that the adult occurred parasitic in some host other than the fly. No evidence favoring the first hypothesis was obtained, as the nematodes from flies when placed in various media such as water, damp

${ }^{1}$ Ann. and Mag. Nat. Hist., Lond., 3 s. (37), v. 7, January, 1861, pp. 29-33, pl. 1A, Figs. 1-4.

${ }^{2}$ Sitzungsb. d. k. Akad. d. Wissensch., Wien, Math.-naturw. Cl., v. 43, 1 Abt. (4), pp. 273-274, 1861.

${ }^{3}$ Proc. Acad. Nat. Sc. Phila. [v. 26, 3 s., v. 4] (2), April-September, 1874, pp. 139-140. 